\title{
DO EMERGING MARKET FIRMS SACRIFICE ECONOMIC VALUE FOR GROWTH?
}

\author{
Seyda Deligonul, Ph.D. and Jana Sacks, Ph.D.
}

USA

\section{ABSTRACT}

In this article, we focus on emerging market firms, often operating with no or negative EVA rendering them financially fragile. We argue that economic distress does not necessarily drive going concern distress, nor does it drive economically unsound performance. We provide a framework for added value performance assessment and analyze emerging market firms in their growth patterns. We develop a pertinent theory to explain the observation of value loss and its relationship to some underlying factors. While emerging market firms may behave in a way in which they indeed destroy economic value, they also usually sustain their ability to deliver a going-concern premium.

\section{KEYWORDS: Financial fragility, emerging market firm, growth, economic value, return on investment, cost of capital, asset specificity, market integration, agency inefficiencies, fragility index, going concern value}

\section{INTRODUCTION}

Emerging market firms have idiosyncratic structures and behavioral patterns to operate at a lower rate of return than their capital costs, yet these firms sustain their business and deliver going concern value. Although they fail to deliver returns above capital cost, they succeed in contemporaneous gains generated by remarkable cash flow. These firms show once more that engendering value is a very delicate balance on the interplay of investment growth, the weighted average cost of capital, and return on invested capital. We explore this conjecture in the context of emerging market companies.

The objective of this paper is to give exposure to emerging market firms' operations and strategy in their economic value management and point out disparities concerning their developed market counterparties. We attempt to show their struggle to generate positive shareholder value despite costly capital. Emerging market firms often face financial fragility and its difficult consequences, driving them to focus on growth. We argue that they grow to achieve a state of steady-going concern value. Such a state can be regarded as the next best thing, in the absence of the contemporary ability to add economic value.

\section{LITERATURE REVIEW}

The literature shows that emerging market companies display some similar traits. The similarities are negative EVA, high cost of capital leading to financial fragility, high growth coupled with mostly slack-financing and fixed-asset specificity.

Verma et al.(2011) report that these firms are based in rapidly developing economies and by 2020, they will collectively surpass $\$ 8$ trillion in revenues, amount roughly equivalent to the S\&P 500 firms now. In the alternative stream, researchers are less flattering. They frequently point out sterility of management and skewed governance structures that perpetuate the status quo (for instance, family-ownership dominance, low sustainability focus). This camp of researchers associates emerging market firms with protected markets, low levels of competition, limited entrepreneurship opportunities, and underdeveloped financial institutions (Krishnan and Kumar K.2003). More often than not, we read about scant capital concentration, the absence of venture capitalists, or a mindset conditioned by capital and resource scarcity.

Lee, Ng (2009) states: "Valuation theory demonstrates that the key economic drivers of firm value are growth, profitability, and risk." Numerous resources, including our data set, show that emerging market companies often struggle to generate positive economic value for their shareholders. Most emerging market firms operate with negative EVA. (Pomerleano 2007) reports negative economic-value-added from a study of firms in seven emerging markets. Erdogan, Berk, and Katircioglu (2000) reach the same conclusion by computing the economic value using two different methods. Both studies demonstrate over time and across the consistent board results. While these companies can generate impressive cash flow, it is often at the expense of their return on invested capital (ROIC). For instance, (Verma et al. 2011), covering the period 2005 to 2009, find that EM firms were able to surpass their peers in developed markets with a cash flow of 33\%, a sales growth $71 \%$, and in an EBITDA margin of 86\%. At the same time, Cao, Jing \& Koller (2006) report in their findings that companies shouldn’t 
pursue growth heroically at the expense of improvements in ROIC.

Is there an intentional management strategy behind these numbers? Specifically, (Austin 2005) documents the case of the Airways Corporation of New Zealand. In this instance, the firm adopts pricing policies on a voluntary constraint that will limit its earnings under a self-imposed condition of zero economic value (ROIC-WACC $=0$ ). This is a unique situation where a firm chooses to deliver positive going concern value by limiting its returns to the cost of capital.

Emerging-market companies are typically financially fragile. Financial fragility means that the cost of capital across industries is relatively high. They exhibit additional risk characteristics to investors such as lack of regulation, questionable enforceability/court system, and they often lack global market integration.

Numerous studies suggest that emerging market firms have a visible bias toward short term funding. This may be problematic because when companies cannot raise new funds, they face the task of repaying or servicing a large burden of short term debts. If an emerging market firm's strategy of investing heavily intangibles is deliberate; in addition to other things, it is intended to reduce its total investment borrowing costs. But at the same time, as their collateral of fixed assets grows, so will the specificity of assets base which again feeds into a higher cost of financing.

Those assets which generate higher value in their current configuration than in a market sale are specialized. Specialized assets can support the value of the firm as a going concern, but they have lower liquation values since they are not portable and cannot be readily redeployed by other businesses. We refer to the pertinent opportunity costs that arise from the asset specificity as stranded costs. The stranded costs increase the financing costs and therefore affect the cost of capital.

Emerging market businesses are rich in specialized assets and therefore suffer from the consequences of being subjected to stranded costs. First, these tangible fixed assets are often worth more in the hands of the current structure than anywhere else. Second, in these firms fixed assets such as plant, equipment, and other specialized tangibles are relatively illiquid. Theirs is a thin market. If these assets were to be disposed of, they would fetch "bargain basement" prices at a loss. Third, at any sign of distress, these assets may be subjected to a preemptive call of liquidation by creditors. Such adverse prospects also undermine the chance of preserving them in their higher value in first-best use. Specifically, the assets will not be purchased by higher-valuing users within the same industry because they too will be suffering from similar problems and financial constraints.

Concerning regulation, (Taussig2011) states that it is evident that these countries have formal and informal mechanisms, which are idiosyncratic, functional and to a degree equivalent to institutional mechanism in developed counterparts. Hail and Lutz (2005) also underscore that firms from countries with more extensive disclosure requirements, stronger securities regulation, and stricter enforcement mechanisms have a significantly lower cost of capital than EM firms. Easley, O'hara (2004) show that differences in the composition of information between public and private information affect the cost of capital. Lack of information accessibility generally increases the cost of capital.

It seems likely that some emerging jurisdictions are either not interested in, or are not prepared to devote the necessary resources to implement their insider dealing legislation. Bhattacharya and Daouk (2002) suggest that enforcement of insider trading regulations lowers firms' cost of capital. "Shareholders will demand a higher rate of return, on average, to compensate for this risk." And also: "We find that the cost of equity in a country, after controlling for several other variables, does not change after the introduction of insider trading laws, but decreases after the first persecution." The authors find that insider trading laws without enforcement has an insignificant effect on the cost of capital across 103 countries studied. These results are reinforced by La Porta et al. (2002). They determine that strong shareholder rights and legal systems are associated with higher equity valuations.

Hail and Lutz (2005) argue, consistent with theory, that the cost of capital effects of strong legal institutions become substantially smaller and, in many cases, statistically insignificant as capital markets become globally more integrated. They state "In segmented markets, the estimated effect on the cost of capital is about 200 basis points.". In another study, Errunza and Miller (2000) focus on what they deem the most important benefit of capital market liberalization, namely, the impact on the cost of capital. An increased level of integration provides grounds for lower levels of the cost of capital. Additionally, 
Harrison et al. (2004) analyze whether greater foreign direct investment (FDI) inflows are associated with a reduction in firmlevel financing constraints, and report that the increase of FDI indeed lowers financing constraints.

One of the main constraints that EM firms face is their access to affordable capital. High WACC levels may keep firms in the financially fragile state longer, making it more difficult to eventually transcend to the "safe" zone, where increasing growth together with solid ROIC enables accelerated expansions in the company value. Cost of capital increases with the level of underdevelopment of the financial markets, lack of regulatory background and/or well-working court system leading to constraints in competition and entrepreneurship opportunities in companies' respective domiciles.

The results in Lee and Islam, (2011) align with the argument that EM firms tend to build cash reserves to be able to smooth out results and protect against possible problems with access to capital. The author's state: "When the financial market is not perfect and external finance is costlier relative to internal finance, a firm's investment is constrained by the lack of available external finance.

Lastly, the literature review points towards emerging market firms exhibiting high growth rates, the growth being typically financed internally with slack or externally short-term debt, collateralized by highly specific fixed asset portfolio.

As early as 1976, Callen, Mathewson, and Mohring report research findings that there is a more pronounced presence of excessive slack in firms with low economic profits. In dynamic environments, emerging market firms who perceive themselves in a growth situation become more risk-averse when facing uncertainty. This causes the firm to build up the slack (Bromiley 2009). In the case of EM companies, liquid assets provide a reserve for growth. Then it is not surprising to find that an available spare input is often a harbinger of scale and scope expansion.

The literature argues that growth firms anticipating financing constraints respond to it by hoarding liquid assets especially cash (Almeida, Campello and Weisbach 2004). The bias toward current needs and liquid assets results in additional slack sacrificing higher yields and increasing marginal costs. Growth is a driver of excessive slack that chips away economic profits. When an emergent market firm faces financial constraints, investment spending for growth will vary with the availability of funds, rather than with the availability of investment opportunities. When constrained in funding for positive net present value investments, an emergent market firm needs to build up slack knowingly that it is sub-optimal. Unlike an unconstrained firm, it needs to hoard resources (non-zero shadow cost), to incur the cost of holding excessive cash.

Various studies report that slack financing provides discretionary flexibility in growth and innovation after current operational needs are met. Slack resources, including financial category, are considered as one of the key considerations in driving strategies for an emerging market firm growth and innovation, but they also seem to contribute to the magnitude of economic loss. Generally, firms pay down debt when profits are high and borrow when profits are low ((O'Brien 2003), thus the slack facilitates ironing out the cash outflows.

In general, pre-growth firms finance fixed assets with equity and therefore the relationship between fixed assets and debt is negative. This expectation proves true for emerging market firms but with a twist. In the emerging market firms, the more tangible the asset-mix is, the higher the long-term debt ratio (Booth, Demirguc-Kunt and Maksimovic 2001). Specifically, as the tangibility of a firm's assets increases, not only does the long-term debt ratio increases but more importantly, the long-term debt gets replaced with relatively more expensive short-term kind. Consequently, a firm with more tangible assets will have higher debt and use more short-term variety. This is inconsistent with a traditional matching argument that long-term assets should be financed with long-term liabilities.

Using their specificity index, Baird and Morrison (Baird and Morrison 2005) find very high asset specificity for all small-scale businesses across the board. Their findings suggest that emerging market firms with their smaller scale are categorically prone to specificity threat. The asset specificity represents a threat because of the rather low re-sale value of highly specific long-term assets. This phenomenon has been observed in EM firms for some decades. (Williamson 1988) underlines the effect of these transaction costs on debt. Since these 'transaction costs of agency' worsen as specificity increases, Williamson argues that the full cost of debt will eventually rise above the full cost of equity. Accordingly, (Harris and Raviv 1990) consistently point out that a firm's higher asset specificity destroys value, especially via firm-specific or transactionspecific assets. 


\section{THEORY DEVELOPMENT / RESEARCH QUESTION}

One of the first observations about emerging market management is their penchant for growth. This is not a coincidence. The growth is necessary because the average cost will fall with the volume of production as long as the marginal cost lies below the average cost. This is indeed a common characteristic that drives the cost/pricing policy in emerging market firms.

Under the conventional model (please see Fig.1), prices are often held up by imperfect competition in the neighborhood of $\mathrm{OG}$, shifting between $\mathrm{OF}$ and $\mathrm{OH}$ as the degree of competition shifts between the full monopoly and hard competition. At $\mathrm{OH}$, prices are slightly above marginal cost (MC), and ordinarily average cost (AC). Unlike the competitive easing in the conventional model, the price shift in emerging market case occurs from cost-push associated with the shifting capitalintensive direction from $\mathrm{AC}$ to $\mathrm{AC}$ ' (sudden expansion of tangible asset base). The emerging-market firm then sells at price $\mathrm{OG}$ just above its new average cost AC'. In this conventional model, profits increase as prices significantly shift from OH to OG. In our model, the increase in profits is relatively small because the price shift is induced by increased costs brought about by an uneconomic substitution of inputs. Thus, the higher return will be small which can only be compensated by the emerging market firm with a relentless need to build up the scale and expand its markets.

\section{Figure 1}

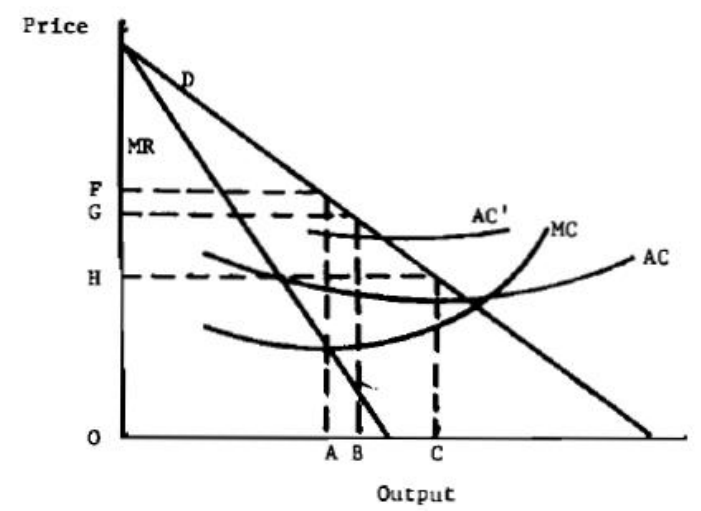

A common characteristic that runs through these industries is their high fixed costs driving their relatively higher average costs over marginal costs. This observation is consistent with the above discussion that these firms have an incentive to develop scale in reaction to their cost structure. Indeed, in favor of operational leverage, Nezlobin finds that with only scale economies a firm keeps its rate of return close to the cost of capital (Nezlobin 2009). Therefore, emerging market firms have an incentive to develop a strong asset base for economic and strategic purposes.

We argue that an emerging market manager does not pursue economic value maximization. As long as the stakeholders are unable to determine whether their observations reflect the true costs of best performance, it is sufficient for management to generate a suitable level of cash flow even it comes at the expense of economic profits. Managers at the firm have an incentive not to report a superb performance since a lower current performance will set a lower expectation for the forthcoming results and help avert a negative earnings surprise. Additionally, a high economic surplus coupled with attractive accounting valuation draws hostile takeover or leveraged buyout attempts, which are a real threat for a small-scale firm with abnormal returns. For avoiding such undesirable consequences, it is plausible to think that the management focuses on growth and chases market power to avert contestability and disciplining threats of new entrants; they target a level of cash flow to ensure a performance deemed successful, but sufficiently low to fend off potential threats.

The recent paradigm of firm treats management discretion as a complex play between multiple stakeholders (institutional investor, analysts, individual investors, rating agencies, hedge funds, creditors, and regulators and so on). Knowing all players are largely autonomous and self-perpetuating the stakeholders formally or informally monitor and regulate the management. Interestingly, the attempt to curb the management's unrestricted discretion does not necessarily result in the 
maximum performance that the firm can economically extract; it ends in a socially agreed target. Such a target sets an earning ceiling and floor around the average cost of capital (not the marginal cost of capital) after factoring in effects of economic volatility, earnings attrition due to general price inflation, and other intangible factors.

The aforementioned view describes managers as consensus-centric value maximizers. Under the stakeholder pressure, they focus on steady improvements in earnings per share within a short-term horizon at the expense of the ability to pursue long-term objectives. Empirical research studying such myopic behavior shows that the respondent corporate executives rank the item share price increase as their second most important objective. It is frequently ahead of such alternatives as improved product portfolio, larger market share, or improvements in company image. In other studies, the managers admit surprisingly that they knowingly sacrifice long term economic value (such as cutting R\&D, delaying maintenance or advertising expenditures, giving up profitable projects) to hit a target, or smooth short-term earnings (Graham, Harvey and Rajgopal 2005).

Assuming the challenges discussed above, emerging market firms tend to walk a tight rope. They grow, but the growth takes place at the expense of shedding economic value.

Using a proposed "consensus profit" model, we investigate the frequency of high-growth, financially fragile emerging market industries. Is there support for the claims of financial fragility, slack building, large growth rates, relatively high WACC, relatively low ROIC, low or negative EVA in current the EM industry data? If so, how prevalent is fragility and consensus profit-type of behavior in the emerging market firms? Can we identify a trend? Can high growth become the ultimate managerial strategy solution for financially fragile firms?

\section{METHODOLOGY}

Given the above description as our baseline scenario, we explore a model in which a firm covers its debt obligations from profits and maximizes its profits without surpassing a consensus profit threshold. The model is simple enough to ignore details such as depreciation, operating expenditure and tax. However, if those details were to be included, the main results from the model would not be different (See Appendix 1 for details). We use the cost of capital (WACC), return on capital (ROIC) and the sustainable growth rate (g) to determine emerging markets industries' state of financial fragility. We look at the number of fragile industries on the total and examine our results for an overall trend.

In our analysis, we work with a dataset consisting of industry averages from industries in global emerging market economies. Dr. Aswath Damodaran of NYU Stern continually publishes annual numbers on his website: http://pages.stern.nyu.edu/ adamodar/. We use selected data sets from this website.

Our data set contains ninety-five industry-specific averages for some variables such as EVA, reinvestment rates, cost of capital, return on capital, ROE, etc., for 2016-2018. The data set excludes financials. The relatively short data time frame is determined by the lack of consistent earlier data reporting for a substantial number of industries. Additionally, earlier data, if existing, is often incomplete and therefore omitted in our analysis.

Initially, we calculate the effect on changes in EVA due to the interplay of WACC, ROIC, and g. We find that holding WACC constant, we observe that ROIC vs. WACC plays a fundamental role. At first, we set ROIC equal to WACC, and see that EVA in this instance experiences a zero change for any level of g. EVA is equal to the amount of firm/industry capital levels and remains constant as any return is wiped out by cost. In the next step, we let ROIC fluctuate in the immediate neighborhood around WACC. We get a small decrease/increase in EVA, depending on ROIC smaller/greater than WACC. What is interesting for our analysis is that the larger the underlying growth rates the smaller the overall absolute change in the EVA. Thus, if EM firms' managers are facing the need to grow, and simultaneously have to operate in a high WACC environment, one of the options available to them is high growth with as little change in their economic value added (EVA) as possible, rendering them a steady-going concern value with an impressive growth record.

In the following chart (Fig. 2), we show this phenomenon. The chart depicts a firm's EVA, given WACC at $10 \%$. ROIC values span from $4 \%$ to $16 \%$, showing a zero change in EVA for ROIC $=$ WACC. ROIC greater than WACC results in positive changes in EVA, and ROIC smaller than WACC is a decrease in EVA. Calculating EVA with an assumption of a large g, i.e. much larger than both ROIC and WACC results show low changes in EVA. The larger the g, the smaller the change in EVA. This shows that in a world of uncertainty regarding ROIC and WACC, EVA can be kept relatively stable 
through high growth. The growth rate $(\mathrm{g})$ is assumed to be between $18 \%-26 \%$ in this example.

Figure 2

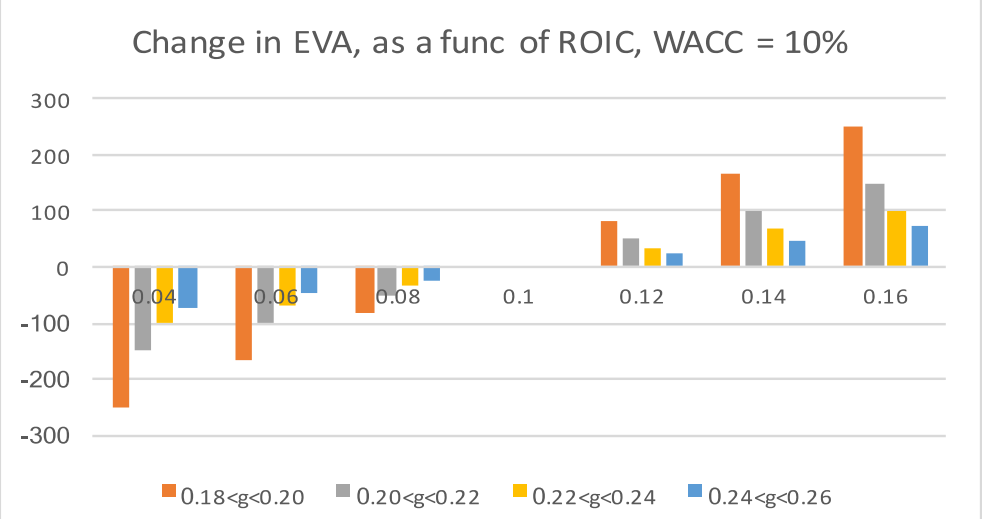

As a result, in our analysis, the emerging market industries' results fall within one of four possible states of the world (Fig. 3). We determine these four states of the world by the relationship of growth rates g, cost of capital WACC, and return on invested capital ROIC. We sort EM industry data to determine which state of the world a particular industry belongs to by labeling them A, B, C, and D. State D is the one where we observe very large growth, surpassing both ROIC and WACC. Therefore, state D is the one we focus on in this article primarily. State A reflects industries with growth rates smaller than both ROIC and WACC, B captures all industries with the cost of capital overshadowing growth and ROIC, and state C shows industries with high ROIC, followed by a smaller g and even smaller WACC. We may refer to industries in the state of the world $\mathrm{C}$ as healthy, sustainable, and value-creating.

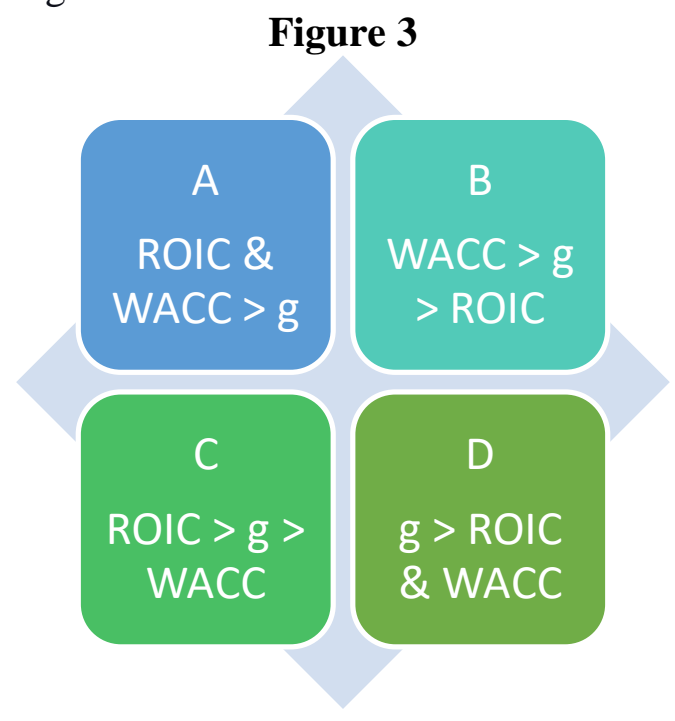

\section{ANALYSIS OF RESULTS}

We investigate results from emerging market industry averages. Our data set consists of 95, 94 and 95 industries for years 2018, 2017, and 2016. We find that on average these industries have consistent negative EVAs.

The following matrix is showing the above-defined four states of the world-A, B, C, and D. It gives an overview of the proportions of each of the states of the world on the total of emerging market industries over time. 


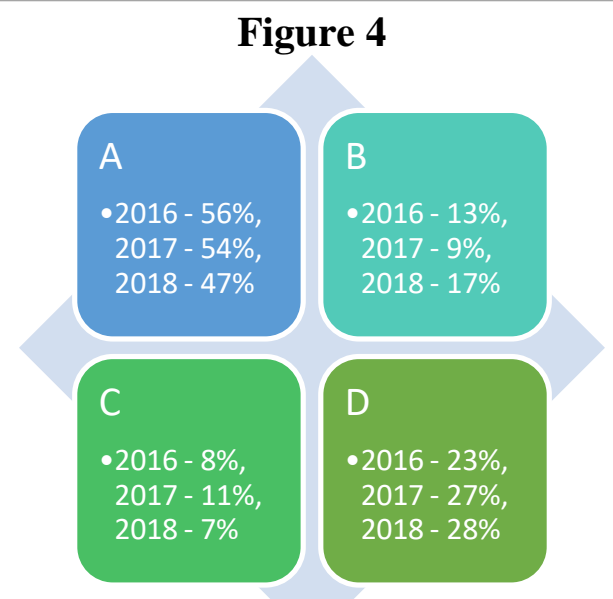

While state A is the most common, it captures industries displaying very low growth rates. A has a decreasing trend. States B and C are roughly trend-less, with greater overall frequencies in B. State B is deemed unsustainable as the cost of capital surpasses both $\mathrm{g}$ and ROIC.

Industries in category $\mathrm{C}$ have been performing well enough to display ROIC covering not only the cost of capital but surpassing growth rate $\mathrm{g}$, as well. This category of industries shows very good results, albeit it represents only a small fraction of the EM industries. It is roughly constant over time at about $9 \%$. These industries represent EM firms that have transcended from a developing industry status to behavior consistent with the majority of developed-world companies, creating positive shareholder value. There are only two industries that fall into this category consistently over the studied three-year period. These two industries are General insurance and household products.

And finally, state D shows the proportion of high growth industries, where growth rates surpass both ROIC and WACC. The industry frequencies in state D is increasing over time (from 23\% in 2016 to $28 \%$ in 2018) (Fig. 5). These industries are our candidates for the aforementioned strategy of keeping a going concern value in the industry through high growth. This high growth strategy is preferred to the one focused solely on increasing shareholder value through maximizing EVA, mostly due to the risk of a high cost of capital. Rather, it is a strategy enabling a relatively steady EVA value, particularly for industries that can generate ROIC that is roughly equal to WACC. The increasing trend suggests that this strategy is possibly gradually becoming appealing to a greater number of corporate managers. See Appendix 2 for a list of emergent high growth industries.

There are eleven industries in our data set that consistently grow at rates outperforming both ROIC and WACC. These industries are Auto parts, Business services, Drugs (biotechnology), Consumer Electronics, Entertainment, Environmental and waste services, HealthCare products, Healthcare information and technology, Recreation, Automotive retail, and Semiconductor equipment. Industries belonging to group D display the most consistency concerning the group members. Additionally, we find a growing trend in group membership. We also note that industries that qualify to become group D members tend to stay at the high growth mode, at least for some time.

Figure 5

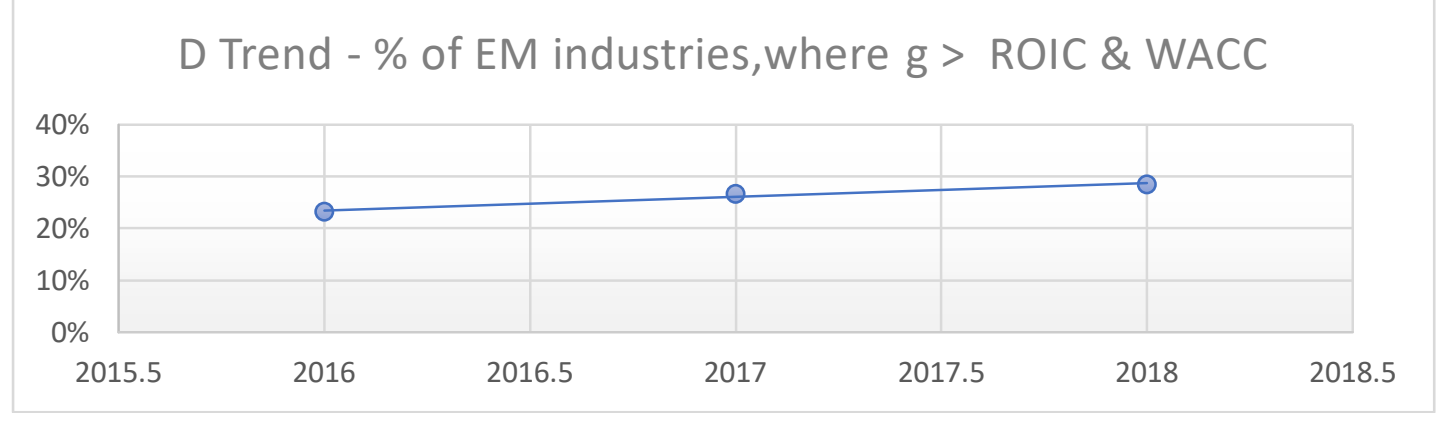


Our model, outlined in Appendix 1, proposes a fragility index measure. Running regressions, we applied this measure on data for industries consistently belonging to category D. Clearly, industries in group D are all growth-driven to ensure going concern value. However, within these, we can still measure their degree of financial fragility, using the fragility index. Our results (see Appendix 3) indicate that most industries belonging consistently to category D are, indeed, financially fragile. $73 \%$ of these industries score a fragility index of less than one, indicating fragility stemming from the high cost of capital and a relatively lower return on capital. Only $27 \%$ of these industries are scoring above one in the fragility measure, indicating financial soundness and value creation despite their high-growth focus. Based on our most recent dataset, these industries are Business services, Healthcare information, and Semiconductor equipment.

\section{CONCLUSION}

The rhetoric in literature reflects two opposing styles when it comes to reporting about an emerging market firm. One group glorifies these firms for their enterprise acumen, and their features driving superior performance. The second devalues them as the product of an underdeveloped environment with idiosyncratic limitations, often delivering negative EVA to investors.

This article attempts to bring both points of view under a unified umbrella. We propose the existence of a deliberate consensus profit strategy for going-concern value creation through growth.

There are practical consequences of our discussion for managing an emerging market firm. These emerge as trade-off instances before the management. First, the emerging market firm takes up the challenge of managing a relentless race between asset base growth and market expansion. A firm that grows twenty percent a year doubles its size every three years. No matter how astute its management is, such a firm cannot operate prudently when annual growth is explosive. Certainly, these firms stretch their already thin capabilities in a managerial capacity, resource allocation, and strategy implementation. Their cost/pricing/investment policy culminates in resource allocation distortion and unnecessary slack as an aggressively expanding venture.

Accordingly, we recognize the merits of emerging market firms in their going concern state against the backdrop of contemporaneous economic value loss. We argue, confirming (Nezlobin 2009), that when the return on capital approaches cost of capital factor (input) allocation distortions occur. Under such distortions, the firm builds up an unabsorbed slack. Since such slack accrues on highly specific assets, the readily deployable resources have less value outside the current ownership structure. Under these conditions, the firm skews the resource substitution rate which in turn drives the management to over- or under-capitalizes and often over-invests. Over investment into a fixed asset base drives a very aggressive growth and results in non-optimal capital structuring.

Short-term debt penchant, asset specificity, and resulting stranded costs, and tangible asset bias render emerging market companies facing a relatively higher cost of capital concerning their developed counterparties. Their return on invested capital is often playing catch up with the costs. In line with our preliminary research, our own data analysis confirms just that. The costs are high, the returns are variable, and the various risk exposure is considerable.

With their fragile structure, the vulnerability of these firms becomes much more visible during downturns in their economic environment. Plausibly, with all else being equal, emerging market firms experience a larger loss of value at the presence of higher systemic risk. Despite their vulnerability, emerging market firms remain viable in the growth model. This dilemma of value loss juxtaposed over a viable business is resolved in this study by introducing a "consensus profit" model capturing a situation where a company is attaining a going concern value, rather than maximizing shareholder value. Specifically, we separate (1) operating with lower returns than the capital cost from (2) being able to build up a contemporaneous value during economic value loss. As a rule, this article argues, neither economic distress drives going concern distress, nor does economic soundness warrants going concern value.

Our study shows that a large portion of global emerging market industries is indeed financially fragile. Financial fragility shows in 93\% of the industries in our dataset as of year-end 2018. We find that some of these industries elect goingconcern value creation in the absence of their ability to maximize their economic value added (EVA). Our analysis shows an increasing trend in this high-growth, going-concern value creation, strategy. It seems to function as a relatively safe stepping 
stone to achieving such levels of return on invested capital (ROIC) and the cost of capital (WACC) that would ultimately warrant positive EVAs.

We envision that an inquiry into the specifics of the process of transcending from a going-concern company to an economic value-maximizing one, in the context of emerging markets, would be a natural extension of this study. On the whole, we believe that emerging markets managerial research would greatly benefit from longer reliable data series; more detailed company-level information, as well as greater reporting transparency.

\section{APPENDIX 1}

$$
\begin{gathered}
F C F=\text { NOPAT }(1-I R) \\
V=\frac{N O P A T(1-I R)}{W A C C-g} \\
g=\text { ROIC } * I R \\
V=\frac{N O P A T\left(1-\frac{g}{R O I C}\right)}{W A C C-g} \\
V=\frac{C a p * R O I C\left(1-\frac{g}{R O I C}\right)}{W A C C-g} \\
V=\operatorname{Cap} * \frac{R O I C-g}{W A C C-g} \\
\ln V=\operatorname{lnCap}+\alpha \ln (R O I C-g)-\beta \ln (W A C C-g) \\
\text { Fragility Index } \\
F=\frac{\alpha}{\beta}
\end{gathered}
$$

\section{Notation:}

$\mathrm{FCF}=$ free cash flow

$\mathrm{IR}=$ reinvestment rate

$\mathrm{V}=$ firm value

$\mathrm{g}=$ long-term growth rate, assumed constant

$\mathrm{F}=$ fragility index

NOPAT $=$ net operating profit after tax

$\mathrm{WACC}=$ cost of capital

ROIC $=$ return on invested capital

$\mathrm{CAP}=$ invested capital 


\section{APPENDIX 2}

High Growth Emerging Market Industries (2016-2018). Industries with growth rates surpassing both ROIC and WACC are denoted with 1 for each year. Industries belonging to groups A, B, or C, are scored 0. Industries that have consistently fallen into category D are captured by in the last column, scoring 1 .

\begin{tabular}{|c|c|c|c|c|}
\hline Industry Name & D - 2018 & D - 2017 & D - 2016 & D consistently over time \\
\hline Advertising & 0 & 0 & 1 & 0 \\
\hline Aerospace/Defense & 0 & 1 & 0 & 0 \\
\hline Air Transport & 0 & 1 & 0 & 0 \\
\hline Apparel & 1 & 0 & 1 & 0 \\
\hline Auto \& Truck & 0 & 0 & 0 & 0 \\
\hline Auto Parts & 1 & 1 & 1 & 1 \\
\hline Bank (Money Center) & 0 & 0 & 0 & 0 \\
\hline Banks (Regional) & 1 & & 0 & 0 \\
\hline Beverage (Alcoholic) & 0 & 0 & 0 & 0 \\
\hline Beverage (Soft) & 0 & 0 & 1 & 0 \\
\hline Broadcasting & 0 & 0 & 0 & 0 \\
\hline Brokerage \& Investment Banking & 1 & 1 & 0 & 0 \\
\hline Building Materials & 0 & 0 & 0 & 0 \\
\hline Business \& Consumer Services & 1 & 1 & 1 & 1 \\
\hline Cable TV & 0 & 0 & 1 & 0 \\
\hline Chemical (Basic) & 0 & 0 & 0 & 0 \\
\hline Chemical (Diversified) & 0 & 1 & 1 & 0 \\
\hline Chemical (Specialty) & 0 & 0 & 0 & 0 \\
\hline Coal \& Related Energy & 0 & 0 & 0 & 0 \\
\hline Computer Services & 0 & 0 & 0 & 0 \\
\hline Computers/Peripherals & 1 & 1 & 0 & 0 \\
\hline Construction Supplies & 0 & 0 & 0 & 0 \\
\hline Diversified & 0 & 0 & 0 & 0 \\
\hline Drugs (Biotechnology) & 1 & 1 & 1 & 1 \\
\hline Drugs (Pharmaceutical) & 0 & 0 & 0 & 0 \\
\hline Education & 0 & 0 & 0 & 0 \\
\hline Electrical Equipment & 1 & 0 & 0 & 0 \\
\hline Electronics (Consumer \& Office) & 1 & 1 & 1 & 1 \\
\hline Electronics (General) & 1 & 1 & 0 & 0 \\
\hline Engineering/Construction & 1 & 0 & 0 & 0 \\
\hline Entertainment & 1 & 1 & 1 & 1 \\
\hline Environmental \& Waste Services & 1 & 1 & 1 & 1 \\
\hline Farming/Agriculture & 0 & 0 & 0 & 0 \\
\hline
\end{tabular}




\begin{tabular}{|c|c|c|c|c|}
\hline Financial Services (Non-bank \& Insurance) & 0 & 0 & 0 & 0 \\
\hline Food Processing & 0 & 0 & 0 & 0 \\
\hline Food Wholesalers & 0 & 0 & 1 & 0 \\
\hline Home Furnishings & 0 & 0 & 0 & 0 \\
\hline Green \& Renewable Energy & 0 & 0 & 1 & 0 \\
\hline Healthcare Products & 1 & 1 & 1 & 1 \\
\hline Healthcare Support Services & 1 & 0 & 0 & 0 \\
\hline Healthcare Information and Technology & 1 & 1 & 1 & 1 \\
\hline Homebuilding & 0 & & & 0 \\
\hline Hospitals/Healthcare Facilities & 0 & 1 & 0 & 0 \\
\hline Hotel/Gaming & 0 & 0 & 0 & 0 \\
\hline Household Products & 0 & 0 & 0 & 0 \\
\hline Information Services & 1 & 0 & 0 & 0 \\
\hline Insurance (General) & 0 & 0 & 0 & 0 \\
\hline Insurance (Life) & 0 & 0 & 0 & 0 \\
\hline Insurance (Prop/Casualty) & 0 & 0 & 0 & 0 \\
\hline Investments \& Asset Management & 0 & 0 & 1 & 0 \\
\hline Machinery & 1 & 0 & 0 & 0 \\
\hline Metals \& Mining & 0 & 0 & 0 & 0 \\
\hline Office Equipment \& Services & 1 & 0 & 0 & 0 \\
\hline Oil/Gas (Integrated) & 0 & 0 & 0 & 0 \\
\hline Oil/Gas (Production and Exploration) & 0 & 0 & 0 & 0 \\
\hline Oil/Gas Distribution & 0 & 0 & 0 & 0 \\
\hline Oilfield Services/Equip. & 0 & 0 & 0 & 0 \\
\hline Packaging \& Container & 0 & 1 & 0 & 0 \\
\hline Paper/Forest Products & 0 & 0 & 0 & 0 \\
\hline Power & 0 & 1 & 0 & 0 \\
\hline Precious Metals & 1 & 1 & 0 & 0 \\
\hline Publishing \& Newspapers & 0 & 0 & 0 & 0 \\
\hline R.E.I.T. & 0 & 0 & 0 & 0 \\
\hline Real Estate (Development) & 1 & 0 & 0 & 0 \\
\hline Real Estate (General/Diversified) & 0 & 0 & 0 & 0 \\
\hline Real Estate (Operations \& Services) & 0 & 0 & 0 & 0 \\
\hline Recreation & 1 & 1 & 1 & 1 \\
\hline Reinsurance & 0 & 0 & 0 & 0 \\
\hline Restaurant/Dining & 0 & 0 & 0 & 0 \\
\hline Retail (Automotive) & 1 & 1 & 1 & 1 \\
\hline Retail (Building Supply) & 0 & 0 & 1 & 0 \\
\hline
\end{tabular}




\begin{tabular}{|l|c|c|c|c|}
\hline Retail (Distributors) & 1 & 1 & 0 & 0 \\
\hline Retail (General) & 0 & 0 & 0 & 0 \\
\hline Retail (Grocery and Food) & 0 & 0 & 0 & 0 \\
\hline Retail (Online) & & 0 & 0 & 0 \\
\hline Retail (Special Lines) & 0 & 0 & 0 & 0 \\
\hline Rubber\& Tires & 0 & 1 & 0 & 0 \\
\hline Semiconductor & 1 & 0 & 1 & 1 \\
\hline Semiconductor Equip & 1 & 1 & 1 & 0 \\
\hline Shipbuilding \& Marine & 0 & 0 & 0 & 0 \\
\hline Shoe & 0 & 0 & 0 & 0 \\
\hline Software (Entertainment) & 0 & 0 & 0 & 0 \\
\hline Software (Internet) & 1 & 0 & 0 & 0 \\
\hline Software (System \& Application) & 0 & 1 & 0 & 0 \\
\hline Steel & 0 & 0 & 0 & 0 \\
\hline Telecom (Wireless) & 0 & 0 & 0 & 0 \\
\hline Telecom. Equipment & 0 & 1 & 0 & 0 \\
\hline Telecom. Services & 0 & 0 & 0 & 0 \\
\hline Tobacco & 0 & 0 & 0 & 0 \\
\hline Transportation & 0 & 0 & 0 & 0 \\
\hline Transportation (Railroads) & 0 & 0 & 0 & 0 \\
\hline Trucking & 0 & 0 & 0 & 0 \\
\hline Utility (General) & 0 & 0 & 0 & 0 \\
\hline Utility (Water) & 0 & 0 & 0 \\
\hline Total Market & 0 & 0 & 0 \\
\hline Total Market (without financials) & 0 & 0 & 0 \\
\hline
\end{tabular}

\section{APPENDIX 3}

Fragility Index-regression results, industries consistently appearing in group D.

\begin{tabular}{|l|r|r|r|}
\hline & \multicolumn{1}{|l|}{ Alpha } & \multicolumn{2}{|l|}{ Fragility Index } \\
\hline Auto Parts & 0.1471 & 0.1507 & $\mathbf{0 . 9 7 6 2}$ \\
\hline Business Services & 0.0233 & 0.0223 & $\mathbf{1 . 0 4 4 8}$ \\
\hline Drugs (bio) & 0.0234 & 0.0257 & $\mathbf{0 . 9 1 0 5}$ \\
\hline Electronics & 0.0554 & 0.0604 & $\mathbf{0 . 9 1 7 2}$ \\
\hline Entertainment & 0.0420 & 0.0492 & $\mathbf{0 . 8 5 3 7}$ \\
\hline Environmental \& Waste Management & 0.0145 & 0.0146 & $\mathbf{0 . 9 9 3 2}$ \\
\hline Healthcare products & 0.0163 & 0.0165 & $\mathbf{0 . 9 8 7 9}$ \\
\hline
\end{tabular}




\begin{tabular}{|l|r|r|r|}
\hline Healthcare info & 0.0097 & 0.0093 & $\mathbf{1 . 0 4 3 0}$ \\
\hline Recreation & 0.0383 & 0.0395 & $\mathbf{0 . 9 6 9 6}$ \\
\hline Auto Retail & 0.0344 & 0.0371 & $\mathbf{0 . 9 2 7 2}$ \\
\hline Semiconductor Equipment & 0.0256 & 0.0255 & $\mathbf{1 . 0 0 3 9}$ \\
\hline
\end{tabular}

\section{REFERENCES}

Adaoglu, C, and Katircioglu, S.T. (2013). Foreign Investor flows and "blue chip" stock returns. International Journal of Emerging Markets, 8(2), p. 170-181.

Almeida, Heitor, Murillo Campello and Michael S. Weisbach (2004), “The Cash Flow Sensitivity of Cash," The Journal of Finance, 59 (4), 1777-1804.

Andrade, Gregor and Steven N. Kaplan (1998), "How costly is financial (not economic) distress? Evidence from highly leveraged transactions that became distressed," The Journal of Finance, 53 (5), 1443-1532.

Asquith, Paul[ and David W. Mullins (1986), "Equity Issues and Offering Dilution,” Journal of Financial Economics, 15 (2), 61-89.

Austin, Lloyd M. (2005), "Benchmarking to economic value added: The case of Airways Corporation of New Zealand Limited," Benchmarking, 12 (2), 138-150.

Baird, Douglas G. and Edward R. Morrison (2005), "Serial Entrepreneurs and Small Business Bankruptcies," Columbia Law Review, 105 (8), 2310-2368.

Barisik, S., Tay, A. (2010). An analysis of financial crisis by early warning systems approach: the case of transition economies and emerging markets (1994-2006 period panel logit model). International Journal of Economic Perspectives, 4(2), p. 403-426.

Bartlett, Christopher A. and Sumantra Ghoshal (2000), "Going global lesson from late movers," Harvard Business Review, 78 (2), 132-142.

Barton, Jan and Paul Simko (2002), "The Balance Sheet as an Earnings Management Constraint. Vol," The Accounting Review, 1 (27), 29-33.

Bekaert, G., Harvey, C.R., Lundblad, C. (2010), "Financial Openness and Productivity", World Development, Vol. 39, No. 1, 1-19.

Bernard, A.B., and Sjoholm, F. (2003). Foreign owners and plant survival. NBER working papers 10039.

Bhattacharrya, U., Daouk, H. (2002), “The World Price of Insider Trading”, The Journal of Finance, Vol. 57, No. 1, 75-108.

Booth, Laurence, Asli Demirguc-Kunt and Vojislav Maksimovic (2001), "Capital structures in developing countries," The Journal of Finance, 56 (1), 87-130.

Bromiley, Philip (2009), “A Prospect Theory Model of Resource Allocation,” Decision Analysis, 6 (3), 124-138,194-195.

Brown, Lawrence D. (2001), “A temporal analysis of earnings surprises: Profits versus losses," Journal of Accounting Research, 39 (2), 221-241.

Callen, Jeffrey, G. F. Mathewson and Herbert Mohring (1976), "The Benefits and Costs of Rate of Return Regulation," The American Economic Review, 66 (3), 290-297.

Cao, B., Jiang, B., and Koller T. (2006). Balancing ROIC and growth to build value. Strategy and Corporate Finance. McKinsey \& Co.

Carpenter, Robert E. and Bruce C. Petersen (2002), "Is the Growth of Small Firms Constrained by Internal Finance?," The Review of Economics and Statistics, 84 (2), 298-309. 
Chen, Y., Gao, Y, Ying G., and Li, J. (2015). Regional financial development and foreign direct investment. Urban Studies, 52(2)., p. 358-373.

Chen, Zeyun (2009), “The choice between real and accounting earnings management," Ph.D. Dissertation, Bauer College of Business, University of Houston, United States -- Texas.

Desai, M.A., Foley, F., and Forbes, K.J. (2007). "Financial constraints and growth: Multinational and local firm responses to currency depreciations". Review of Financial Studies. 21(6), p. 2857-2888.

Douma, S., George, R., and Kabir, R. (2006). "Foreign and domestic ownership, business groups, and firm performance: Evidence from a large emerging market." Strategic Management Journal, 27(7), p. 637-657.

Easley, D., O’Hara, M. (2004), "Information and the Cost of Capital”, The Journal of Finance, Vol. 59, No. 4, $1553-1583$.

Erdogan, Oral, Niyazi Berk and Erol Katircioglu (2000), "The economic profit approach in firm performance measurement," Emerging Markets, Finance \& Trade, 36 (5), 54-74.

Errunza, V.R., Miller, D.P. (2000), "Market Segmentation and the Cost of Capital in International Equity Markets", The Journal of Financial and Quantitative Analysis, Vol. 35. No. 4, 577-600.

Garicano, L., and Steinwender, C. (2013). Survive another day: Using changes in the composition of investments to measure the cost of credit constraints. CEP discussion paper no. 1188.

Gebhardt, W.R., Lee, C.M, Swaminathan, B. (2001), “Toward Implied Cost of Capital”, Journal of Accounting Research, Vol. 39, No.1, 135-176.

Girma, S., and Gorg, H. (2002). Foreign direct investment, spillovers and absorptive capacity: Evidence from quantile regressions. Research Paper 2002/14.

Gordon, Myron J. (1959). "Dividends, Earnings and Stock Prices". Review of Economics and Statistics. 41 (2): 99-105

Graham, John R, Campbell R. Harvey and Shiva Rajgopal (2005), "The economic implications of corporate financial reporting," Journal of Accounting \& Economics, 40 (1/3), 3-73.

Hail, L., Leuz, C. (2006), "International Differences in the Cost of Equity Capital: Do Legal Institutions and Securities Regulation Matter?”, Journal of Accounting Research, Vol 44, No. 3, 485-531.

Harris, Milton and Artur Raviv (1990), "Capital Structure and the Informational Role of Debt," The Journal of Finance, 45 (2), 321-349.

Hintosova, A.B., and Kubikova, Z. (2016). The effect of the degree of foreign ownership on firm's performance. Review of Economic Perspectives, 16(1), p. 29-44.

Kolasa, M., Rubaszek, M., and Taglioni, D. (2010). Firms in the great global recession: The role of foreign ownership and financial dependence. National Bank of Poland working paper no. 77.

Krishnan, Rishikesha T. and Kumar K, eds. (2003), Emerging Market Companies Ascending the Value Curve: Rationale, Motivation \& Strategies.

Krugman, Paul (2000). Technology, trade and factor prices. Journal of International Economics, 50 (1), p. 51-71.

La Porta, Rafael, Florencio Lopez-De-Silanes, Andrei Shleifer and Robert W. Vishny (1997), "Legal determinants of external finance," The Journal of Finance, 52 (3), 1131-1150.

Lee, C.M., Ng, D. (2009), “Journal of Investing”, Winter 2009.

Lee, Inmoo, Scott Lochhead, Scott Ritter and Quanshui Zhao (1996), “The costs of raising capital," The Journal of Financial Research, 19 (1), 59.

Lintner, J. (1965) The Valuation of Risk Assets and the Selection of Risky Investments in Stock Portfolios and Capital Budgets. Review of Economics and Statistics. 47:1, pp. 13-37

Lup, Daniela (2009), "Status and surprises: Causes of reaction to new information about firm performance," Ph.D. Dissertation, The University of Chicago, United States -- Illinois. 
Markarian, Garen (2005), “Analyst forecasts, earnings management, and insider trading patterns,” Ph.D. Dissertation, Case Western Reserve University, United States -- Ohio.

Marris, Robin (1963). “A Model of the "Managerial” Enterprise”. The Quarterly Journal of Economics, Vol. 77, No. 2, p. 185209.

Nezlobin, Alexander A. (2009), "Economic uses of accounting information," Ph.D. Dissertation, Stanford University, United States -- California.

O'Brien, Jonathan P. (2003), “The capital structure implications of pursuing a strategy of innovation," Strategic Management Journal, 24 (5), 415-431.

Obstfeld, M. (1994), "Risk-taking, Global Diversification, and Growth", The American Economic Review, Vol. 84, No.5, 1310-1329.

Peng, Mike W. (2003), "Institutional transitions and strategic choices," The Academy of Management Review, 28 (2), 275296.

Penrose, Edith (1959) The Theory of the Growth of the Firm (Basil, Blackwell, Oxford) pp viii, 272.

Pomerleano, Michael (1998), "The East Asian Crisis and Corporate Finances - the Untold Micro Story," Malaysian Journal of Economic Studies, 35 (1/2), 113-135.

Pomerleano, Michael (2007), "Three essays on financial crisis," Ph.D. Dissertation, Graduate School of Art and Science, Harvard University, United States -- Massachusetts.

Posner, Richard A. (1969), "Natural Monopoly and Its Regulation,” Stanford Law Review, 21 (3), 548-643.

Sappington, David (1980), "Strategic Firm Behavior Under a Dynamic Regulatory Adjustment Process," The Rand Journal of Economics, 11 (1), 360-372.

Skarica, B. (2014). Determinants of non-performing loans in Central and Eastern European Countries. Financial Theory and Practice, 38(1), p. 37-59.

Stein, Jeremy C. (1989), "Efficient Capital Markets, Inefficient Firms: A Model of Myopic Corporate Behavior," The Quarterly Journal of Economics, 104 (4), 655-669.

Stewart, G.B. (1994), "EVA: Fast and fantasy", Journal of Applied Corporate Finance, 7, p. 71-84.

Stulz, R. (1999), "Globalization, Corporate Finance and the Cost of Capital”, Journal of Applied Corporate Finance, Vol. 12, No. 3, 7-25.

Taussig, Markus D. (2011), “Essays on Firm Strategy and Performance in Emerging Economies,” Ph.D. Dissertation, Harvard University, United States -- Massachusetts.

Verma, Sharad, Kanika Sanghi, Holger Michaelis, Dupoux Patrick, Dinesh Khanna and Philippe Peters (2011), "Companies on the Move: Rising Stars from Rapidly Developing Economies are Reshaping Global Industries,” Boston Consulting Group.

Williamson, Oliver E. (1988), “Corporate finance and corporate governance,” The Journal of Finance, 43 (3), 567-591.

Williamson, Oliver E. (1991), "Strategizing, economizing, and economic organization,” Strategic Management Journal, 12 , 75-94.

Williamson, Oliver E. (1993), “Opportunism and Its Critics,” Managerial and Decision Economics, 14 (2), 97-107. 